\title{
Do Development Economists Matter?
}

\section{Gerald M. Meier}

When I approached the World Bank a few years ago about a conference and volume on the Pioneers in Development, I could think of no better organiser and co-editor than Dudley Seers - himself a pioneer. We were to meet in June, 1983 in Washington and begin editing the Pioneers when he arrived ill from his last mission to Fiji. His final writings were on the plane and related to the editing we were about to do, and to activities that he was next to undertake in Trinidad and Shanghai after Washington.

To the end, it was characteristic for Dudley Seers to be planning for the future: the present dissolved into the future. This personal zest and future orientation carried over to his writings and to the work of IDS. In that spirit, I should now like to look back in order to look forward about a subject that concerned Dudley: what have development economists accomplished since those pioneering days? Do development economists matter?

In his Nobel lecture, Theodore Schultz [1980] stated: 'Most of the people in the world are poor, so if we knew the economics of being poor we would know much of the economics that really matters'. I would agree that the economics of poverty is the economics that really matters. But do development economists matter?

Early on, Dudley had something to say about this question. He wrote about 'Why visiting economists fail' (1962) and about 'The limitations of the special case' (1967). While urging that 'the help that governments need most desperately is advice on how to stimulate development', he believed that 'conventional economics does not have a great deal to offer by way of useful advice'. He stressed the relativism of economics - the danger in transferring economic propositions uncritically from the special case of the developed industrial economies to the newly emergent nations. And he stated that 'economists are of very little use working on the problems of underdeveloped economies, until they have done so for many years, and then only if they are unusually adaptable'.

Now, some 20 years later, can we say a little more on this subject? There is no question that there have been some remarkable achievements in the development record over the past four decades. Never before in history has the condition of the poor of the world improved so much in such a short period. Given the rise in various indices of development, whether monetary or non-monetary, one can certainly contend that development economists must have mattered for realising the achievements in the development record. The success stories have not depended on a country's initial conditions but rather on the adoption of appropriate policies. In some countries at some times, economic advisers have been influential. In many other countries, however, the development record has been disappointing. Appropriate policies have not been adopted, and development economists have not been listened to.

Preparatory to my initial experience of lecturing in a developing country - Pakistan in 1958 - my mentor Emile Despres, who had been on the first Ford Foundation mission to Pakistan, wrote me these words of advice:

Economics in Pakistan is in pretty sorry shape. Among the academics, economics is conceived of as a sort of esoteric lore having nothing to do with anything in the world of actuality. They would like you to pitch your lectures at a very fancy, highbrow level, using the most recherché terminology and the fanciest diagrams and dropping as many names in your discourse as possible. I hope you will do just the opposite of what the customers want. Stress the problem-solving value of economics as its only real justification. Keep it very elementary. Stress that modern economics is chiefly concerned with the economics of advanced economies, and that although it is useful in dealing with problems of underdeveloped countries, it has to be applied with discretion, amending some assumptions and all that.

Despite, the attempt in the Five Year plan to emphasise the need for changes in administrative practice, agricultural extension, and other sweeping institutional changes, along with improvements in technology, there is a tendency in Pakistan, as in India and I suspect other countries, to regard the public investment programme as the heart of the plan. Development is thought of, first and foremost, as investment. I am sure that this emphasis is wrong in Pakistan's case. Government controls have the economy in a straightjacket, to a much greater degree than in India, and the misallocation of resources is extreme. The political 
situation, of course, is one of marked weakness, but the civil servants could perhaps do a good deal if they would, despite the weakness at the political level.

Despres was then already concerned about the disadvantages of import substituting industrialisation, the persistence of unemployment and underemployment, and inequality in income and wealth. But such concerns were not then - and are not now - being listened to in many of the less developed countries. Why do development economists continue to be ignored?

Since the $1960 \mathrm{~s}$ there has been a neoclassical resurgence in development economics. But more than this is nceded if the disappointments in the development record are to be overcome. A major disappointment has been that the poorest of the poor nations have made the least progress: neoclassical prescriptions are not likely to solve the structural problems of these countries.

Nor are such prescriptions effective for overcoming other disappointments in the development record: namely, the high rates of population growth, the pervasiveness of unemployment and underemployment, the increasing number of people living in absolute poverty, the inequality in distribution, and the lack of political development. If development economists are to matter more, they must give more attention to these problems. And to do this, they will have to go beyond neoclassical economics to more analysis of disequilibria, the dynamics of structural change, and the incorporation of non-economic factors.

Some known neoclassical prescriptions, however, might be effective and helpful. Some other policies that go beyond neoclassical economics are also endorsed by most development economists. From the evolution of development thought and the policy lessons of the last four decades, many development economists would now agree on a set of appropriate policies. My central question thus becomes: even when economists do know how to put things right, and they do agree on the remedial policy, why are they still not listened to? Why are these policies not adopted?

The answer may simply be that the economist cannot even present his advice to the policy maker. Perhaps the country's ultimate decision maker would say, as Dr. Banda of Malawi has stated:

I am the boss here. Why beat about the bush? I am the boss. I am responsible for this country, the welfare of the ordinary people in the villages, men and women, boys and girls. Whatever the rules and regulations, practices and usage, etiquette in other countries ... whatever the etiquette between the officials and politicians, between Permanent Secretaries and their Ministers, whatever the usage in other countries - not here, not here! I am the boss. I am responsible.

A leader ... who depends on others, even his own officials or outside experts, is a prisoner. And I never want to be a prisoner on any subject, not one. I accept advice from my so-called experts, so-called advisers, so-called specialists only when their advice agrees with my own ideas and not at any other time.

Therefore, we do not permit any, not even the World Bank, to tell us what to do because we know what we want [Pryor 1986].

But this statement can be discounted as indulgence in a bit of dramatic hyperbole. For Malawi has established an excellent group of economists in government, and Dr. Banda takes pride in the growth of the University of Malawi and its graduation of a sizeable number of economists, and the World Bank's policy-based lending to Malawi has been significant.

Nonetheless, even if the economist can present his case, there may still be a lack of understanding by the policy maker. I would not, however, attribute this to demographic considerations and lack of higher education in small developing countries, as does Arnold Harberger. ${ }^{1}$ On the contrary, the burden must lie on the economist as adviser to be understandable and persuasive in the giving of his advice. Only too often advice is too subtle or too complicated to be persuasive.

In minimising Ricardo's contribution to the repeal of the Corn Laws, George Stigler states that Ricardo's passage on Portugal and England and wine and cloth is beyond the comprehension of ordinary citizens, and that after reading this passage the import that the layman is likely to embrace is not the English theory of free trade but a bottle of Portuguese wine [Stigler 1976:58]. Today, however, Ricardo's three paragraphs remain the essence of simplicity and clarity in comparison with Bhagwati's survey article on comparative advantage [Bhagwati 1969] or Ethier's exposition of higher dimensional factor endowments theory [Ethier 1974]. Rare indeed is the policy maker in any count ry who can understand the modern theory of comparative advantage.

Not only are policy prescriptions presented to the policy maker in too complicated a form - they also frequently defy any feasible application. Where is

${ }^{1}$ Harberger contends that in a typical small developing country of $6 \mathrm{mn}$ people. less than $1.2 \mathrm{mn}$ would now be over the age of 40 , and of these less than one per cent would typically have received any higher education. 'Those who take fully to heart the razor-sharp logic of economics will be at an inherent disadvantage relative to those who feel comfortable with a world view that is at once fuzzier. but more flexible, softer. but more malleable ... The smaller the leadership elite, the more are characteristics peculiar to it including its own cliques, factions and rivalries - likely to play a dominant role in defining pressures and points of resistance' [Harberger 1988:345, 353]. 
there any government that can compute and administer the lump sum and non-distortionary taxes and subsidies of neoclassical welfare economics? For most developing countries, even the machinery for direct income taxes is rudimentary. While the economist only too often deals with the first-best optimal policy, the government must live with the second best or third best in any hierarchy of policy choices. As Dudley Seers pointed out, visiting cconomists often fail because they are unable to make the necessary appraisal of the socioeconomic structure and the capacity of the administration in the developing country [Seers 1962:331].

Moreover, the political calendar has a short time horizon, whereas the economist considers longer term tendencies. But as Keynes observed:

The long run is a misleading guide to current affairs. In the long run we are all dead. Economists set themselves too easy, too useless a task if in tempestuous seasons they can only tell us that when the storm is long past the ocean is flat again

[Keynes 1923]

These explanations, however, have too much of an ad hoc character and are not entirely satisfying. Can we offer a more systematic explanation of why policy makers do what they do? For this purpose we turn to the insights of the 'new political economy'.

\section{The New Political Economy}

By the 'new political economy' I mean the use of neoclassical economic methodology to explain the political determinants of policy making. Such a positive theory of political behaviour does not assume that government is an exogenous force but is instead endogenous, and the policies it institutes can be explained by such neoclassical concepts as optimisation, marginalism, equilibrium. The analysis at tempts to disaggregate and operationalise the 'state', and is composed of various strands of thought: public choice, collective choice, transaction costs and property rights, rent seeking and directly unproductive activities. Political rationality is postulated. In the terminology of game theory, forms of political analysis involve identifying (a) the game form - the players, their strategies and the extensive form of the game, and (b) identifying the preferences of the participants and institutional actors. In this analysis the government cannot be viewed as a Platonic Guardian nor a benevolent dictator achieving Pareto efficiency or maximising a social welfare function. No longer can the development economist refer to a Pigou-Meade or Bergson-Samuelson type of planner. ${ }^{2}$

Denying that governments are the agencies of public interest, the new political economy has gone on to designate a typology of government that focuses on the state as a Leviathan or predatory state, or as factional, or as bureaucratic. The Leviathan model interprets government as secking profits and rents from the activities in which it engages. Such an objective explains the imposition of quantitative restrictions, tariffs, bulk buying, controls over wholesale and retail trade. Another objective of Leviathan is likely to be net revenue maximisation. In this predatory view of the nature of government, the state preys on its citizens, with an insatiable appetite for revenue that it consumes for its own sake [Findlay and Wilson 1987:290].

Findlay and Wilson remind us, however, that the state may also be productive. The provision of public goods (security, law and order, irrigation, roads) raises the productivity of the economy above the level that woul d exist without the state (anarchy). Viewing the state as an institution that is intrinsically both productive and potentially predatory in character, Findlay and Wilson attempt to capture this dual character in a simple general equilibrium model. The sovereign is interested in the surplus of revenue over expenditure and therefore equates marginal revenue to the marginal cost of hiring more government workers. ${ }^{3}$

Findlay and Wilson view the state as a 'natural monopoly', and the 'surplus' that the state maximises is a sort of monopoly 'rent' that the sovereign can enjoy. But they then postulate that the surplus originally enjoyed purely by the sovereign attracts a horde of office seekers anxious to get their hands on some of it. A monarchial-type Leviathan may thus be transformed into a bureaucratic Leviathan. A budgetmaximising hypothesis is then attributed to the behaviour of the bureaucratic Leviathan.

At the other extreme from a Leviathan acting in an autonomous fashion is the interpretation of the state as a passive reflection of interest groups. Viewed in principal-agent terms, citizens are the principals and politicians the agents who are to conform to the objectives of the principals. The principals are especially interested in transfers - in policy issues of who gets what.

\footnotetext{
${ }^{2}$ On the contrary, as Robert Bates observes, 'recent experiences in Africa and elsewhere make it clear that the preference of governments often bears litıle correspondence to any idealisation of the public interest. Rather, governments engage in bureaucratic accumulation and act so as to enhance the wealth and power of those who derive their incomes from the public sector; they also act on behalf of private factions, be they social classes, military cliques, or ethnic groups. They engage in economic redistribution, often from the poor to the rich and at the expense of economic growth. These are central themes in policy formation in Africa and their prominence serves to discredit any approach based on a conviction that governments are agencies of the public interest' [Bates 1983:169].

"In a similar analy'sis, Lal postulates that the sovereign would seek to equate the marginal cost of public employees with the marginal tax revenue from the output produced by the remaining workers [Lal 1986:11].
} 
Where elections matter, the politicians undertake transfers so as to maximise the possibility of reelection. Where the politicians worry about a takeover, they may try to avoid contestability and deter entrants by courting their support through favourable measures of distribution. ${ }^{4}$

The modelling of a factional state has been especially prominent in the explanation of agricultural policies. As Michael Lipton has incisively emphasised, the 'urban bias' of governments results in the transfer of surpluses from agriculture to the urban, industrial sector. Where low prices are paid to farmers, urban consumers benefit. Where state marketing boards implicitly tax the rural sector, the government's revenue from export sales is often used on non-traded services supplied by the urban sector (government employees in bureaucracies, the military, and state industrial enterprises) [Lipton 1977].

Where governments subsidise inputs for farmers, the benefits of these subsidies are appropriated by a minority of large-scale farmers. Where an overvalued exchange rate is maintained, domestic food producers face higher levels of competition from inexpensive foreign foodstuffs. And where import substitution policies protect local industries, the prices of goods that farmers consume are higher than world prices.

Analysing such relations between governments and agricultural markets in Africa, Robert Bates concludes:

'Food policy in Africa appears to represent a form of political settlement designed to bring peaceful relations between African governments and their urban constituents. It is a settlement whose costs tend to be borne by the farmers. ${ }^{5}$ It is not only the worker who cares about food prices. Employers care about food prices because food is a wages good; with higher food prices, wages rise and, all else being equal, profits fall ... When urban unrest begins among food consumers, political discontent often rapidly spreads to upper echelons of the polity: to those whose incomes come from profits, not wages, and to those in charge of major bureaucracies. Political regimes that are unable to supply low-cost food are seen as dangerously incompetent and as failing to protect the interests

4 As Lal notes. 'Even a revonuc-maximising predatory state is unlikely to raise taxes to the level which reduces peasant incomes to the subsistence level, as well before that the current controllers of the multiproduct natural monopoly providing the public goods of 'law and order' and 'security', which is the state, will find that their industry is contestable. The contestants could be either internal or external rivals. The level of taxes which will be sustainable depends upon the barriers to entry - including physical (geographical). technological (military) as well as ideological (including religion) which allow the maximum 'natural' rent to be extracted by any controller of the state" [Lal 1986:121].

Similar obscrvations could be made for Latin American countries. But in Asian countries - such as Malaysia, Indonesia, Korea, Taiwan and Thailand - the governments have looked to the rural sector as an important element of support [Sachs 1985:558-9]. of key elements of the social order' [Bates 1983:169-70].

Although a political economy approach has been applied most frequently to food price policy, we could also interpret trade policy, stabilisation policy, or balance of payments adjustments as the outcome of political pressures extended by various interest groups. We should also analyse the activities of the public bureaucracy in order to illuminate why governments do what they do. The political economy of public bureaucracies merits special emphasis because of the large public sector, extensive public projects, and state owned enterprises in a developing country. It is necessary to capture both the bureaucratic and political dimensions of administrative performance.

The new economics of organisation can help do this by allowing us to incorporate a contractual perspective on organisational relationships, a focus on hierarchical control, and formal analysis via principal-agent models. To minimise problems of adverse selection and moral hazard it is rational for a government to internalise contracting relationships by extending its own bureaucracy instead of engaging in market-like transactions with private contractors.

The administration of government regulations acquires particular importance when markets do not clear and there are disequilibrium prices, for then bureaucratic allocation can grant favours, premia, and rents to particular individuals or groups. Through these administratively conferred benefits or through the threat of sanctions, bureaucratic controls can be used to organise political support and maintain the regime in power.

These interpretations of the role of the state have the merit of departing from the economist's usual notion of a benevolent well-informed state acting in the public interest. The actual behaviour of a government is far from the economist's technocratic view of it maximising a social welfare function subject to resource and technological constraints. The political economy perspective suggests that a more realistic interpretation of why governments do what they do can be based on the concepts of a political market, government preferences, political resources, political costs, political constraints, political risk aversion, political loss aversion, and the demand for and supply of policy outputs. Nonetheless, although this approach introduces some political realism, its neoclassical dimensions are overdone.

\section{Limitations of the New Political Economy}

Although the new political economy has opened one or two windows in the black box of the state, it is still quite limited - especially in its relevance for developing countries. The neoclassical dimensions of 
the new political economy are too narrow once we go outside the liberal democratic state. Does the new political economy apply when the LDC is not a decent ralised democratic state but instead a centralised dictatorial or authoritarian state? Its major contributions have been to the morc developed countries in which political participation is high, voters play a major role, legislative bodies are also major actors, and elections have importance. Does it apply when we go beyond game theoretic or rational choice models? Much of the new political economy is based on a pluralist model in which public policy is the result of the pressures placed upon decision makers by large numbers of competing groups in society. The state provides a more or less neutral institutional and procedural framework in which conflicting groups form coalitions, and policy change occurs because different coalitions of interests manage to gain power and impose their preferred solution on society.

This approach, however, tells us little about the actual process of decision making and does not recognise any independence for political leaders or policy makers to shape alternatives. Moreover, the model has limited transferability to most of the developing countries, where:

interest aggregating structures tend to be weak. Political parties, for example, may be more important as mechanisms by which elites control mass followings than as means by which interests are articulated from below to government leadership. This is particularly true in regimes in which single or dominant parties direct the political state. Elsewhere, parties may be vehicles for the personal ambitions of individual politicians who are divorced from any real commitment to achieving goals beyond the acquisition of government jobs and their distribution to loyal followers. In other countries, technocratic military regimes have abolished parties.

Interest groups may be similarly ineffective as structures for presenting collective demands to political leadership. Interest associations frequently are captive organisations of ruling parties, exist only at the sufferance of the government, or, like parties, are formed for the single purpose of protecting the political interests of their leadership

[F]requently there are few organisations in existence that are capable of representing the interests of broad categories of citizens and formulating policies responsive to their particular needs. Those few that are effective in this role tend to be the creatures of wealthy and powerful groups such as bankers, industrialists, and landowners [Grindle 1980:16].

Another difficulty with the formal models of the new political economy lies in the formulation of an appropriate utility function. To say that the state maximises its own utility is vacuous without further specification, but the possible variety of utility functions is extensive, and many cannot be predicted but only identified ex post. Nor in view of external pressures from overseas donors and international agencies can it be said that the government always acts according to its own interests and preferences.

Although different maximands may be considered, new political economy always views government as being a rational maximiser. But bounded rationality may prevail, social-psychological elements in decision making should be considered, and the government may be 'satisficing' instead of optimising - in accord with Hirschman's 'coping state'.

As opposed to the rationality hypothesis, we may often find a behavioural perspective to be more illuminating in incorporating concepts and hypotheses from the older political economy. We might better explain policy choices by understanding the role and consequences of ideology, nationalism, classes, elites, power, status, patron-client relations, political culture, the structure of the state itself - its rules and institutions. Beyond neoclassical political economy, we should recognise the cultural, social and psychological determinants of political change. By neglecting this older perspective, the models of the new political economy tend to be mathematically frigid, with form dominating over substance, and technique receiving more emphasis than empirical relevance. Moreover, the models focus only on decision-making with respect to policy choice. But as a coalition precedent to that decision we should first analyse the problem of agenda formation. In this connection, Hirschman has distinguished between 'pressing' and autonomously 'chosen' problems. Pressing problems are those that are forced on the policy makers through pressure from injured or interested outside parties'. Chosen problems are those that decision makers 'have picked out of thin air' as a result of their own perceptions and preferences. Pressing problems are generally those in which a perception of crisis is apparent [Hirschman 1963:254-335].

After the policy making decision there must also be implementation. In the models of the new political economy political activity is focused on the input stage of the policy process, when interest groups influence the policy making decision. In contrast, we should recognise that in developing countries it is at the output stage - at the stage of implementation and enforcement - that a large portion of individual and collective demand-making occurs, interests are represented, and there is a resolution of conflict [Grindle 1980:15-18].

Many of the most important policies established by political elites involve distributive and redistributive measures: 
In the context of very scarce resources, who gets what and how much is of central concern to the populace. In order to have any impact on decision making, many in a developing country have found the implementation phase of the policy process to be particularly suited to their needs. In attempts to acquire government goods and services, individuals and groups find it especially rewarding to focus their demand-making efforts on officials and agencies empowered to distribute benefits, or on politicians who may have influence over individual allocations. The factions, patron-client linkages, ethnic ties, and personal coalitions that are often the basis of political activity are well suited to making individualised demands on the bureaucratic apparatus for the allocation of goods and services. This means that the implementation process may be the major arena in which individuals and groups are able to pursue conflicting interests and compete for access to scarce resources. It may even be the principal nexus of the interaction between the government and the citizenry, between officials and their constituents [Grindle 1980:18-19].

Furthermore the credibility and sustainability of a policy - attributes that are essential for policy reform - are determined during the implementation phase. If policy reform is to succeed, it is then that conflict, resistance, and reversibility must be avoided. Since political activity concentrates on the implementation process, it is much more difficult to predict the efficacy of policies than would be indicated by the new political economy's confinement to decision making with respect merely to the policy choice.

Given the inadequacy of the new political economy, we must seek a more eclectic approach that combines the old and new political economy. As an illustration of this broader but necessarily more informal analysis, let us now consider the behaviour of a developing country's government with respect to trade policy, and particularly its attraction to import substituting industrialisation (ISI).

\section{Political Economy of Trade Policy}

Development economists can certainly present logically valid arguments for protection of import substitution industries. There is merit to the infant industry argument under certain conditions namely, the industry enjoys dynamic learning effects that generate irreversible technological external economies that cannot be captured by the protected industry; the protection is limited in time; and the protection enables the industry to realise sufficiently lower costs such that the initial excess costs of the industry will be repaid with an economic rate of return equal to that earned on other investments.

There is also merit to protection arguments for industry when there is factor price disequilibrium in a dual labour market such that the urban wage in industry is greater than its social opportunity cost. And if a country can exercise international market power it might protect an import-competing industry in order to improve its commodity terms of trade. Rarely, however, has protection been instituted because of these arguments, let alone applied by a government in a technically correct fashion. In contrast, protection in practice has been adopted for reasons best explained through a political economy perspective.

Trade policy is placed on the agenda as a pressing problem. Balance of payments crises and the foreign exchange constraint require the state to take some action. As Hirschman expresses it:

the state loses its august character of a sovereign pursuing its own objectives and initiating policies to this end; rather, it is seen as coping, as best it can, with a variety of emergencies, as constantly plugging holes, and stopping a wheel from creaking by applying a bit of grease in a hurry. Note that this conception of the coping state goes farther than the interest-group or bureaucratic-politics approaches; these are still concerned with improving our understanding of the state's action, rather than with affirming that most of the time the state does not act, but reacts [Hirschman 1975:389].

This pressing problem of the balance of payments also becomes a privilege problem, in the sense of gaining the attention of the policy maker, because it is reinforced by the ideology of nationalism and the appeal of economic independence. In a newly emergent country the economics of development may initially be an economics of discontent as the politically independent government seeks to overcome its colonial legacy, is attracted to the values of modernisation, and the correlative policy of 'industrialisation from the top downward'.

Governments also respond to political demands of various interests. In some countries ISI is promoted by a development coalition composed of industrialists, urban wage earners, bureaucrats, and intellectuals. In others, there is what Peter Evans calls a 'triple alliance' of multinational corporations, elite local capital, and the 'state bourgeoisie' [Evans 1979].

A formal model of lobbying by the capitalists has been presented by Wellisz and Findlay (1984). The trade regime is determined by the government, which has a 'restriction-formation function' reflecting its own preferences - that is, its ideology, the self interests of the governing group, public support considerations, international obligations, etc. Lobbying expenditures by pro- and anti-restriction factions enter the restriction formation function as arguments and link the political with the economic system. The political 
system is viewed as an institutionalised market in conflict resolution, and the endogenous tariffs that emerge are the terms of trade reflecting the lower organisational costs of the particularised (i.e. protectionist) interests relative to the generalised (i.e. free trade) interests [Magee 1984:46].

Economic resources are used to obtain politically created rents. The restriction of manufacturing imports raises the marginal product of labour in manufacturing, leading to an increase in rent on capital. For the government, a large or even the major part of its revenues is derived from tariffs. An alliance between a revenue-maximising or surplus-maximising Leviathan and protection-seeking manufacturers would then lead to a tariff that is higher than one maximising revenue but that falls short of outright prohibition. Tariffs can be interpreted as 'prices' that clear political markets. In the presence of uncertainty, however, the risk-avoiding manufacturers will prefer a quota to a tariff. The government could then gain revenue through the sale of import licences. Rarely, however, is this done. Instead the government uses the import-licensing regime to dispense patronage within the ruling bu reaucratic and political elite [Findlay and Wellisz 1986:225-6].

In this model, the government tends to be soft - that is, vulnerable to group pressures, and the trade systems tend to be highly distorted. Under these circumstances, "favour seeking' flourishes. To the extent that real resources are used in lobbying for trade restrictions or in revenue or rent-seeking, such activities may redistribute income within the economy, imposing costs on some sectors and bringing benefits to others. The general conclusion is that high levels of protection in LDCs, which are totally irrational in terms of the conventional theory of trade and welfare, are perfectly explicable in terms of the rational selfinterest of the relevant pressure groups in the economy [Wellisz and Findlay 1984:148-9, 151].

Although protectionist policies may coincide with the interests of dominant groups in society, this need not be the result of a weak state being in fact dominated by societal interests, but instead may be the result of the conviction on the part of state elites that these policies are the most feasible for achieving national development, or it may be a result of interactions of bargaining, conflict, and compromise between state elites and social classes. Instead of clear domination of the state by specific interests, policies may be influenced by the development ideologies adopted by state elites, or by the leadership ('political entrepreneurship') of specific individuals, or by the political accommodations and bargains that are struck between state elites and various social groupings [Grindle 1986:18-19]. In societies with strong states, the government may impose policy over the objection of particularistic interests.
For a variety of reasons, therefore, a host of policies have been adopted in an ad hoc and indiscriminate fashion in a number of developing count ries, resulting in a restrictive trade regime that is quite different from an economically rational system of protection. For a Leviathan that seeks revenue, tariffs appeal. But high tariffs or quantitative restrictions are also imposed on imports of the final commodity, whereas intermediate inputs have low or no tariffs, thereby giving high effective rates of protection on the domestic value added. The final assembly of imported components may also be subsidised by low rates of interest, easy access to credit, foreign exchange allowances, provision of indust rial estates, low public utility rates, and favourable tax allowances. At the same time, the subsidisation of the import competing industries tends to be embedded in a general environment of inflation and the maintenance of an overvalued exchange rate that becomes a covert way to tax the agricultural sector.

Whether weak or strong, governments have not adopted the first best policies in the neoclassical policy hierarchy. From the syndrome of policies associated with ISI, profits in local currency and rents have been high even though the domestic resource cost is excessive and domestic value added may even be negative at world prices. At the same time, inequalities in income distribution have been aggravated, and employment creation in the urban import replacement industrial sector has not kept pace with rural-urban migration. Overvalued exchange rates have encouraged capital flight, and foreign borrowing by governments have often gone to finance the private sector's accumulation of foreign assets, rather than to an increase in export capacity: the foreign exchange constraint has not been relaxed.

For some countries a turnaround from ISI to export promotion (EP) has occurred after the first easy stage of import substitution. For purposes of policy appraisal it is important to consider why this turnaround occurs: it is not simply because of laissez faire on the part of the government, for export led development has generally been state-led. True, economists have certainly emphasised the deficiencies and adverse effects of ISI. Their advice has been effective at some times in some countries, ${ }^{6}$ but to bear fruit their ideas have to fall on fertile ground: there were other reasons for the turnaround in policy making.

Actual experience may itself be more telling than neoclassical prescriptions. As Bhagwati observes, 'Many developing countries learned [the policy lessons] the hard way; by following ISI policies too long and seeing the fortunate few pursuing the EP strategy do much better. Perhaps learning by others'

\footnotetext{
- For the substantial influence of economists on new trade policies in Tawain in the 1950s. sce Little 1979:474-5.
} 
doing and one's own undoing is the most common form of education!' [Bhagwati 1988:41]. There is indeed an international demonstration effect in government policies and some countries may simply import and imitate the policies practised in other countries. Under international leverage through the elites of the World Bank, IMF, or OECD there may also be some suasion to import the EP policies.

In a formal sense, we can of course say that a government adopts EP policies when the costs to the government of not doing so become excessive. In this connection, a major reason for the shift to EP lies in the perception by the Leviathan state that its organic interest in autonomy is better served by the outwardorientation policy [Findlay 1986:21]. The ISI policy eventually founders on the shortage of foreign exchange as requirements for intermediate imports and capital goods rise more rapidly than domestic production can replace imports of final goods. Foreign aid and more external borrowing become necessary to relax the foreign exchange constraint. Thus, instead of continuing along the ever-more difficult path of ISI, why not turn to EP and capitalise on the unprecedented world trade boom of the 1960s and early 1970s? Diversification of export markets and supply sources could actually ensure that increased participation in the world economy, as measured by higher trade rations, would result in less dependency and more autonomy, cont rary to dependency ideology [Findlay 1986:22].

A switch to EP involves not only a change in trade policies but also exchange rate adjustment and stabilisation measures. The differing exchange and trade regimes in Latin America and Asia bring out another force contributing to the more effective EP policies in Asia - namely, long-term differences in the balance of power between urban and rural interests. Latin American governments have found their most important constituencies among urban workers and capitalists. Trade restrictions tend to shift income from the agricultural and mineral producing sectors toward the industrial and service sectors. The relative power of the agricultural sector has declined since the Great Depression of the 1930s, and the agricultural sector has been relatively weak, with peasants only loosely organised. Moreover, political unrest is most dangerous in the cities.

In contrast, governments in Asia have felt the pressing need to win support of, or at least to appease, the stronger rural sector (Korea, Taiwan, Malaysia, Indonesia, Thailand). ${ }^{7}$ The link between rural influence and export promotion is the first step in instituting an export programme. But once export promoting policies get under way, urban-industrial exporters become their own lobbyists and eventually

\footnotetext{
7 This paragraph presents the argument of Jeffrey Sachs [see Sachs: 1985: $350 \mathrm{ff}$.
}

become the dominant political force in favour of an undervalued exchange rate, with rural interests losing their relative influence.

The switch to EP does not appear, however, to be a function of any particular type of political regime: it has occurred in regimes as different as those of South Korea, Thailand, and Brazil (in the 1960s). The policy shift from ISI to EP has also taken place within count ries with essentially unchanged political regimes, such as South Korea. On the other hand, ISI has continually been pursued in some countries despite radical differences and changes in their political regimes - for example, for more than half a century, in Egypt and Turkey (until 1980).

\section{Conclusion}

To conclude: some four decades ago the subject of development was thrust upon economists. Since then economists have had to respond with policy prescriptions to solve pressing problems. Their ideas have mattered - but my cause now is that development economists should matter more. There have been disappointments and disenchantment, and the early optimism has gone. If development economists are now to be more influential, the subject of development economics must move beyond neoclassical economics. And if an idea is to prevail as the actual policy of a particular government, it must obtain support from those who have political power. Development economists must therefore open the black box of the state. We cannot assume a benevolent state acting in the public interest and equipped with needed information, knowledge and policy instruments to achieve a social welfare function or Pareto efficiency. We should therefore give attention to the new political economy's effort to endogenise the policy maker and we should recognise some insights in the analysis of public choice and collective choice.

But to explain policy choices we must also go beyond a neoclassical analysis of policy-making to incorporate elements of the older political economy and political sociology, so as to have a richer view of the politics of policy formation. Moreover, we must give as much consideration to the process of agenda formation and implementation as to the policy decision itself. From this more comprehensive view of the policy making process in practice, we might better understand how to correct non-market failure and overcome resistance to policy reform.

At a fundamental level, the challenge remains to achieve Dudley Seers' objective of inst ituting interdisciplinary studies that will yield relevant theories translatable into effective policies. Since its founding conference, IDS has mattered a great deal in making a notable contribution in this direction. We should hope that its next generation of development economists will matter even more. 


\section{References}

Bates, Robert H., 1983, 'Governments and agricultural markets in Africa', in D. Galc Johnson (ed.). The Role of Markets in World Food, Westview Press, Bonlder, CO Part 4

Bhagwati, Jagdish, 1969, 'The pure theory of international trade: a survey', in J. N. Bhagwati, Trade. Tariffs and Growth, MIT Press, Cambridge, MA

-1988, 'Export-promoting trade strategy: issues and evidence', The World Bank Research Observer, vol 3 no 1 , January

Ethier, W., 1974. "Some of the theorems of international trade with many goods and factors', Jounal of International Economics, vol 4 no 2, May

Evans, Peter, 1979, Dependent Development: The Allince of Multinational. State and Local Capital in Brazil, Princeton University Press, Princeton, NJ

Findlay, Ronald, 1986. 'Trade, development and the state', Yale University Economic Growth Center, 25th Annjversary Symposium, April 11-13, mimeo

-and Wellisz, Stanley, 1986, 'Tariffs, quotas and domesticcontent protection: some political economy considerations", Public Choice, 50:221

-and Wilson, John D., 1987, 'The political economy of Leviathan', in Assaf Razin and Efraim Sadka (eds.), Economic Policy in Theory and Practice, Macmillan Press, New York

Grindle, Merilee S., 1980, Politics and Policy Implomentation in the Third World. Princeton University Press, Princeton, NJ

-1986, State and Conntriside: Development Policy and Agrarian Politics in Latin America, Johns Hopkins Press, Baltimore, MD

Harberger, Arnold C., 1988, 'On policy making and economic policy in small developing count ries', in R. Dombusch and F. Leslie, C. H. Helmers (eds.), The Open Economy, Economic Development Institute of the World Bank, Washington D.C.

Hirschman, Albert O., 1963, Journey's Tovard Progress, W. W. Norton \& Co, New York

-1975. 'Policymaking and policy analysis in Latin A merica - a return journey", Policy' Sciences, 6: 385-402
Keynes, J. M., 1923, Tract on Monetary Reform, Macmillan and $\mathrm{Co}$, London

Lal, Deepak, 1986, 'The political economy of industrialisation in primary product exporting economies: some cautionary tales'. International Economic Association Eighth World Congress, October

Lipton, Michael, 1977, Why Poor People Stay Poor: Urban Bias in World Development. Harvard University Press, Cambridge, $\mathrm{MA}$

Little, I. M. D., 1979, 'An economic reconnaissance', in Walter Galenson (ed.), Economic Growth and Structural Change in Taivan. Cornell University Press, Ithaca

Magee, Stephen P., 1984, 'Endogenous tariff theory: a survey', in D. C. Colander (ed.), Neoclassical Political Economy, Ballinger Publishing Co., Cambridge, MA

Pryor, Fred, 1986, 'The political economy of poverty, equity and growth - Malawi', draft mimeo paper presented to the World Bank's Lisbon workshop July 7-16 (VPERS, World Bank. June 1986)

Sachs, Jeffrey, 1985, 'External debt and macroeconomic performance in Latin America and East Asia', Brookings Papers on Economic Activity, 2: 523-64

Schultz, R. W., 1980, 'Nobel Lecture: The Economics of Being Poor', Joumal of Political Economy', vol 88 no 4 , Augnst: 639-51

Seers, Dudley, 1962, 'Why visiting economists fail', Journal of Political Economy, vol LXX no 4. August: $325-38$

-1967. 'The limitations of the special case', in Kurt Martin and John Knapp (eds.), The Teaching of Development Economics, Frank Cass and Co. Ltd., London

Stigler, George, 1976, 'Do economists matter?' Southern Economic Journal 42, January

Wellisz, Stanislaw and Findlay, Ronald, 1984, 'Protection and rent-seeking in developing countries', in D. C. Colander (ed.), Neoclassical Political Economy, Ballinger Publishing Co., Cambridge, MA 